\title{
Lead Pollution of Shooting Range Soils
}

\author{
Nicholas Sehube ${ }^{a}$, Rosemary Kelebemang ${ }^{a}$, Otlogetswe Totolo ${ }^{a}$, Masego Laetsang ${ }^{b}$, \\ Obed Kamwi ${ }^{c}$ and Pogisego Dinake ${ }^{a, k}$
}

\author{
${ }^{a}$ Department of Chemical and Forensic Sciences, Botswana International University of Science and Technology, BIUST, \\ Plot 10071, Boseja-Khurumela, Private Bag 16, Palapye, Botswana. \\ ${ }^{b}$ Botswana Geoscience Institute (BGI), Private Bag 0014, Lobatse, Botswana. \\ ${ }^{c}$ Safety Health and Environment, Botswana Defence Force, BDF, Sir Seretse Khama Barracks, Private Bag X06, \\ Mogoditshane, Botswana.
}

Received 7 June 2016, revised 29 November 2016, accepted 19 December 2016.

\begin{abstract}
A total of eight military shooting ranges were used for this study. Soil samples were collected at each of the eight shooting ranges at the berm, target line, 50 and $100 \mathrm{~m}$ from berm. In all of the shooting ranges investigated the highest total lead (Pb) concentrations were found in the berm soils. Elevated $\mathrm{Pb}$ concentrations of $38406.87 \mathrm{mg} \mathrm{kg}^{-1}$ were found in the berm soils of TAB shooting range. Most of the shooting range soils contained high levels of $\mathrm{Pb}$ in the range above $2000 \mathrm{mg} \mathrm{kg}^{-1}$ far exceeding the United States Environmental Protection Agency (USEPA) critical value of $400 \mathrm{mg} \mathrm{kg}^{-1}$. The predominant weathering products in these shooting ranges were cerussite $\left(\mathrm{PbCO}_{3}\right)$ and hydrocerussite $\left(\mathrm{Pb}_{3}\left(\mathrm{CO}_{3}\right)_{2}(\mathrm{OH})_{2}\right)$. The Synthetic Precipitation Leaching Procedure (SPLP) Pb concentrations exceeded the USEPA $0.015 \mathrm{mg} \mathrm{kg}^{-1}$ critical level of hazardous waste indicating possible contamination of surface and groundwater.
\end{abstract}

KEYWORDS

Soil pollution, $\mathrm{Pb}$, berm, ammunition, shooting range.

\section{Introduction}

The contamination of shooting range soils with lead $(\mathrm{Pb})$ emanating from shots and bullets has received increased attention due to the elevated amounts of $\mathrm{Pb}$ in these places and the adverse health effects associated with exposure to $\mathrm{Pb}$. The following physical characteristics have provided for $\mathrm{Pb}$ to be a preferred metal in ammunition manufacture; low melting point $\left(327.4^{\circ} \mathrm{C}\right)$, high density $\left(11.34 \mathrm{~g} \mathrm{~cm}^{-3}\right)$, high resistance to corrosion and its high malleability. ${ }^{1} \mathrm{~Pb}$ has detrimental effects to humans, animals and the ecosystem. The adverse health effects in humans are more pronounced in children. Low levels of $\mathrm{Pb}$, as low as $10 \mu \mathrm{g} \mathrm{dl}^{-1}$, in children's bodies can lead to conditions such as damage to the brain and nervous system, behavior and learning problems (e.g. hyperactivity and aggressiveness), slowed growth, hearing problems, headaches and impairment of vision and motor skills. ${ }^{2}$ Exposure to $\mathrm{Pb}$ in adults can cause difficulties during pregnancy, reproductive problems in both men and women (such as low birth weight, birth defects and decreased fertility), high blood pressure, digestive problems, neurological disorders, memory and concentration problems, muscle and joint pain and kidney dysfunction. ${ }^{2}$ In the past few years, studies have shown that there is an elevated amount of $\mathrm{Pb}$ contamination in the soils of shooting ranges. ${ }^{3}$ To highlight that environmental pollution from $\mathrm{Pb}$ at shooting ranges is a worldwide concern, approximately 58300 tonnes ${ }^{4}$ of $\mathrm{Pb}$ is accumulated into the USA soils annually and $300 \mathrm{~g} \mathrm{~kg}^{-15}$ of $\mathrm{Pb}$ has been documented in the topsoil of a clay-shooting range in the Netherlands. In Denmark $\mathrm{Pb}$ concentration of $100000 \mathrm{~g} \mathrm{~kg}^{-16}$ has been reported. Pb quantities of 24500,54000 , and $10620 \mathrm{~g} \mathrm{~kg}^{-1}$ have also been reported in Sweden ${ }^{7}$, Finland ${ }^{8}$ and England ${ }^{9}$, respectively. It has been found that the large quantities of $\mathrm{Pb}$ found in the soil at the shooting ranges have direct relationship with the ease through which the

* To whom correspondence should be addressed. E-mail: dinakep@biust.ac.bw
$\mathrm{Pb}$ bullet can be transformed into species that can easily dissolve and diffuse into the environment. ${ }^{10}$ In the soil $\mathrm{Pb}$ bullets can undergo variety of reactions such as oxidation, carbonation and hydration which convert them into soluble compounds. ${ }^{11}$ It is of paramount importance to note that the reaction transformation of $\mathrm{Pb}$ into these species is site-specific and may or may not occur at each individual range. There are factors that affect the rate of oxidation, carbonation and hydration processes such as type of soil, soil $\mathrm{pH}$, organic matter content and high amounts of rainfall. ${ }^{12}$ When $\mathrm{Pb}$ is exposed to air it can be oxidised into compounds like massicot $(\mathrm{PbO})$ and the presence of organic matter can transform $\mathrm{Pb}$ into cerussite $\left(\mathrm{PbCO}_{3}\right)$. The other compounds into which $\mathrm{Pb}$ can be transformed into include hydrocerussite $\left(\mathrm{Pb}_{3}\left(\mathrm{CO}_{3}\right)_{2}(\mathrm{OH})_{2}\right.$, anglesite $(\mathrm{PbSO} 4)$, hydroxypyromorphite $\left(\mathrm{Pb}_{5}\left(\mathrm{PO}_{4}\right)_{3} \mathrm{OH}\right)$ and chloropyromorphite $\left(\mathrm{Pb}_{5}\left(\mathrm{PO}_{4}\right)_{3} \mathrm{Cl}\right){ }^{13}$ The processes of chemical transformation can be shown in equations as follows; 1) transformation of metallic $\mathrm{Pb}$ into massicot $(\mathrm{Pb}(\mathrm{s})+$ $\left.\left.4 \mathrm{H}^{+}+\mathrm{O}_{2} \rightarrow \mathrm{PbO}(\mathrm{s})+2 \mathrm{H}_{2} \mathrm{O}\right) ; 2\right)$ formation of cerussite $\left(\mathrm{CO}_{2}+\right.$ $\left.\mathrm{H}_{2} \mathrm{O} \rightarrow \mathrm{HCO}_{3}^{-} ; \mathrm{PbO}(\mathrm{s})+\mathrm{HCO}_{3}^{-} \rightarrow \mathrm{PbCO}_{3}(\mathrm{~s})+\mathrm{OH}^{-}\right)$and 3) formation of hydrocerussite $\left(3 \mathrm{PbO}+2 \mathrm{HCO}_{3}^{-}+\mathrm{H}_{2} \mathrm{O} \rightarrow\right.$ $\left.\mathrm{Pb}_{3}\left(\mathrm{CO}_{3}\right)_{2}(\mathrm{OH})_{2}(\mathrm{~s})+2 \mathrm{OH}^{-}\right)$. Past research study has shown that an average of $5 \%$ of metallic $\mathrm{Pb}$ pellet had been converted to $\mathrm{Pb}$ carbonate and $\mathrm{Pb}$ sulphate over a period of 20-25 years in a shooting range soils in Sweden. ${ }^{14}$ When it rains these compounds may be dissolved and the storm runoff water may move the $\mathrm{Pb}$ in solution into the environment surrounding the shooting ranges endangering the lives of humans, wildlife and vegetation. At acidic $\mathrm{pH}$ of water, the dissolved $\mathrm{Pb}$ concentration in the soil will increase and thereby increasing the amount of $\mathrm{Pb}$ in the storm runoff water. To show that soil type has an effect on the mobility of $\mathrm{Pb}$, a research study reported increased $\mathrm{Pb}$ concentrations up to $100 \mathrm{~cm}$ depth into the soil profile. ${ }^{15}$ More than $200 \mathrm{mg} \mathrm{kg}^{-1}$ of $\mathrm{Pb}$ has been detected at depths of up to $90-100 \mathrm{~cm}$ 
at a shooting range soil. Research by Chen's group in 2002 quantified $\mathrm{Pb}$ concentrations of $262 \mathrm{~g} \mathrm{~kg}^{-1}$ at a depth of up to $100 \mathrm{~cm}$ in a shooting range characterized by calcareous soils bearing high organic carbon and high $\mathrm{pH} .{ }^{16}$

$\mathrm{Pb}$ contamination has not only been restricted to shooting range soils but pollution in water has also been detected in surface water samples at places close to shooting ranges. ${ }^{17,18}$ The study by Stansley and co-investigators indicated elevated levels of $\mathrm{Pb}$ of $1270 \mu \mathrm{g} \mathrm{L}^{-1}$ in surface water within the shot fall zone of the impact berm compared to nearby control areas of less than $1 \mu \mathrm{g} \mathrm{L}^{-1}$ of total $\mathrm{Pb}$ within short distance from the shooting range. ${ }^{18}$ In 1988, VanBon recorded $\mathrm{Pb}$ concentrations of $1300 \mu \mathrm{g} \mathrm{L}^{-1}$ in surface water on a clay shooting range. ${ }^{5}$ Increased levels of $\mathrm{Pb}$ were also recorded in Florida's firing range at a concentration of $289 \mu \mathrm{g} \mathrm{L}^{-19}$ near the firing line while quantities of $473 \mu \mathrm{g} \mathrm{L}^{-1}$ have been reported by Craig and co-workers ${ }^{17}$.

In addition to soil and water contamination, elevated levels of $\mathrm{Pb}$ in plants found in the shooting ranges have also been reported. High quantities of $\mathrm{Pb}$ were found in the roots of plants. ${ }^{19} \mathrm{~A}$ decrease in plant density has been observed within a shot-fall zone with $\mathrm{Pb}$ concentrations of $1500-10500 \mathrm{mg} \mathrm{kg}{ }^{-1} \cdot{ }^{20} \mathrm{~Pb}$ in plants has also been reported to reduce plant dry weight, photosynthesis, water absorption and root growth. ${ }^{21}$

Botswana should not be an exception to $\mathrm{Pb}$ pollution in shooting ranges since it uses ammunition regularly for training at shooting ranges by the Botswana Defence Force (BDF), Botswana Police Service (BPS), Botswana Prisons Service (BPS) and the Department of Wildlife and National Parks. However, since their inception there has not been a single research study on the environmental impact of $\mathrm{Pb}$ at the shooting ranges used by these government bodies. The only research on pollution from $\mathrm{Pb}$ that has been done focused on vehicular emissions. ${ }^{22,23}$ Kgosiesele and colleagues have reported an annual $\mathrm{Pb}$ from battery waste of 46000 tones and this could also be contributing to the amount of soil contamination from $\mathrm{Pb} .^{24}$ The objectives of this study are 1) quantification and evaluation of the prevalence of $\mathrm{Pb}$ pollutant from ammunitions in the soils from shooting ranges in Botswana, 2) carry out Synthetic Precipitation Leaching Procedure (SPLP) to simulate acid rain to ascertain for the mobility and possible contamination of both surface and groundwater, and 3) providing feedback to stakeholders, in particular the government of the Republic of Botswana, to assist on policy formulation. Based on the extent of soil contamination, best range management practices will be recommended to the range users and stakeholders such as soil clean-ups and $\mathrm{Pb}$ immobiliza- tion to minimize mobility of this toxic metal to water sources and nearby agricultural soils.

\section{Experimental}

\subsection{Description and Characteristics of Sampling Locations}

A total of eight shooting ranges were selected in southern and central Botswana. The eight sampling sites were located in or near the villages of Mogoditshane (MOG, GPS coordinates: $-24^{\circ} 37^{\prime} 36.98^{\prime}$ South, $25^{\circ} 51^{\prime} 56.02^{\prime}$ East), Mochudi (TSH, GPS coordinates: $-24^{\circ} 24^{\prime} 59.99^{\prime}$ South $26^{\circ} 08^{\prime} 60.00^{\prime}$ East), Makanke (MAK, GPS coordinates: $24^{\circ} 33^{\prime} 11.00^{\prime}$ South $25^{\circ} 48^{\prime} 14.00^{\prime}$ East), and Thebephatshwa (TAB, GPS coordinates: $24^{\circ} 13^{\prime} 18.40^{\prime}$ South $25^{\circ} 20^{\prime} 53.80^{\prime}$ East) in southern Botswana and other shooting ranges such as Shoshong (SHO R1 and SHO R2, GPS coordinates: $-23^{\circ} 01^{\prime} 60.00^{\prime}$ South $26^{\circ} 30^{\prime} 59.99^{\prime}$ East) and Paje (PAJ R1 and PAJ R2, GPS coordinates: $-22^{\circ} 16^{\prime} 12.00^{\prime}$ South $26^{\circ} 47^{\prime} 14.39^{\prime}$ East) in the central Botswana as shown in the map below (Fig. 1a). For each shooting range, a background soil sample was collected $200 \mathrm{~m}$ outside the shooting range. The shooting activities taking place at these sites involve use of small arms assault rifles mainly of the $0.50^{\prime}, 5.56 \mathrm{~mm}$ and $7.62 \mathrm{~mm}$ calibres.

All the shooting ranges investigated have been in operation for over 20 years as shown in Table 1 . The soils found in the sampled shooting ranges occur mostly in three classes (Table 1). The chromic luvisols which are moderately deep to very deep and moderately well to slightly excessively drained, strong brown to dark red, sandy loams to clay loams. There are also luvic arenosols which may be deep to very deep, well to somewhat excessively drained, yellowish brown to red, fine and finemedium sands to loamy fine sands. The ferric luvisols were also

Table 1 Shooting range year of establishment and the corresponding soil types found at the shooting ranges.

\begin{tabular}{lll}
\hline Range & $\begin{array}{l}\text { Year of } \\
\text { establishment }\end{array}$ & Soil classification \\
\hline MOG & 1977 & Ferric Luvisols \\
TSH & 1998 & Ferric Luvisols \\
MAK & 1983 & Chromic Luvisols \\
TAB & 1995 & Chromic Luvisols \\
SHO R1 and SHO R2 & 1995 and 1988 & Chromic Luvisols \\
& respectively & \\
PAJ R1 and PAJ R2 & 1996 (both) & Luvic Arenosols
\end{tabular}

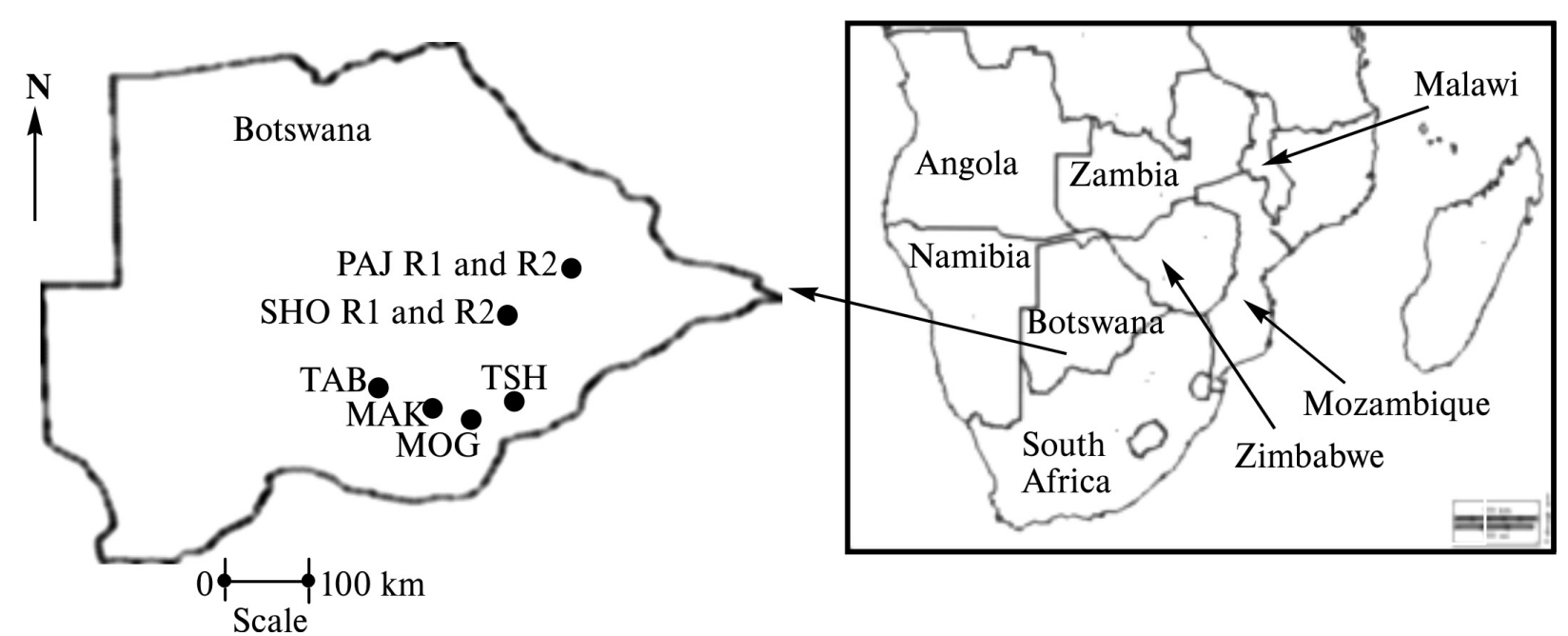

Figure 1 (a) Location of shooting ranges sampled in the map of Botswana. (b) Map showing southern African countries. 
found in most of the shooting ranges studied and this class of soils is moderately deep to very deep, imperfectly to moderately well drained, dark brown to red, sandy clay loams to clays. ${ }^{25}$

The rainfall patterns indicate that most of the shooting ranges receive more rainfall during the months of October to March as shown in Fig. 2 below. These sites experience high amounts of rainfall in the summer and little to no rain during the winter season. The summer season covers the months of September to April with only four months of winter, May to August. The summer seasons can record high amounts of rainfall, as much as over $300 \mathrm{~mm}$, as experienced by $\mathrm{SHO}$ shooting ranges during the month of December.

\subsection{Field Sampling of Shooting Range Soils}

A total of 48 soil samples were collected from each shooting range to a depth of $20 \mathrm{~cm}$ from the earth surface using a soil recovery probe. The soil samples were collected in quadruplicates at three sampling areas on the berm, target line, 50 and $100 \mathrm{~m}$ from the target line along a central transect (Fig. 3). Each sampling area was circular with a radius of $150 \mathrm{~cm}$. Background

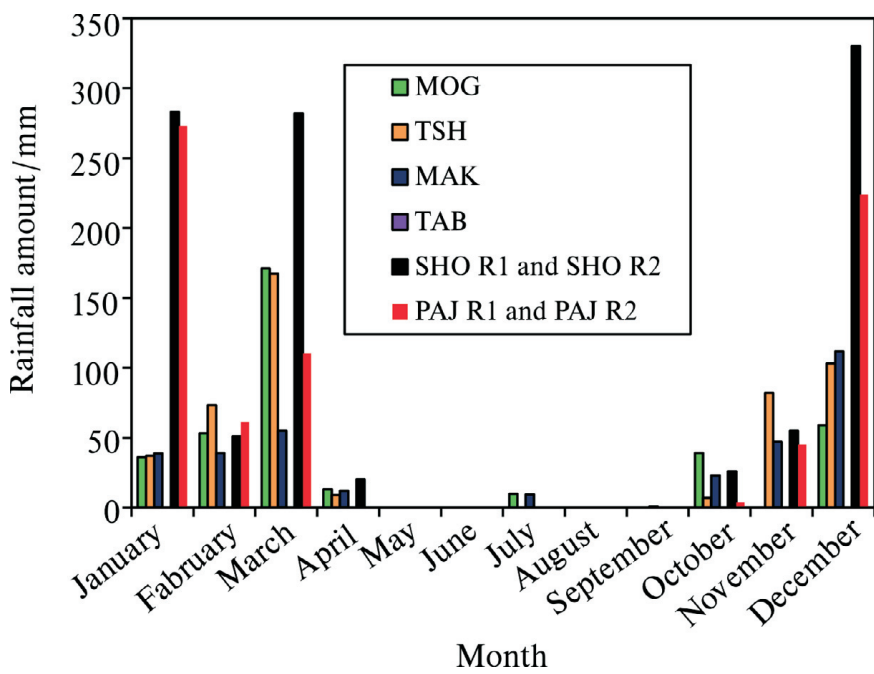

Figure 2 Rainfall amounts at the sampled sites for the period July 2013 to June 2014.
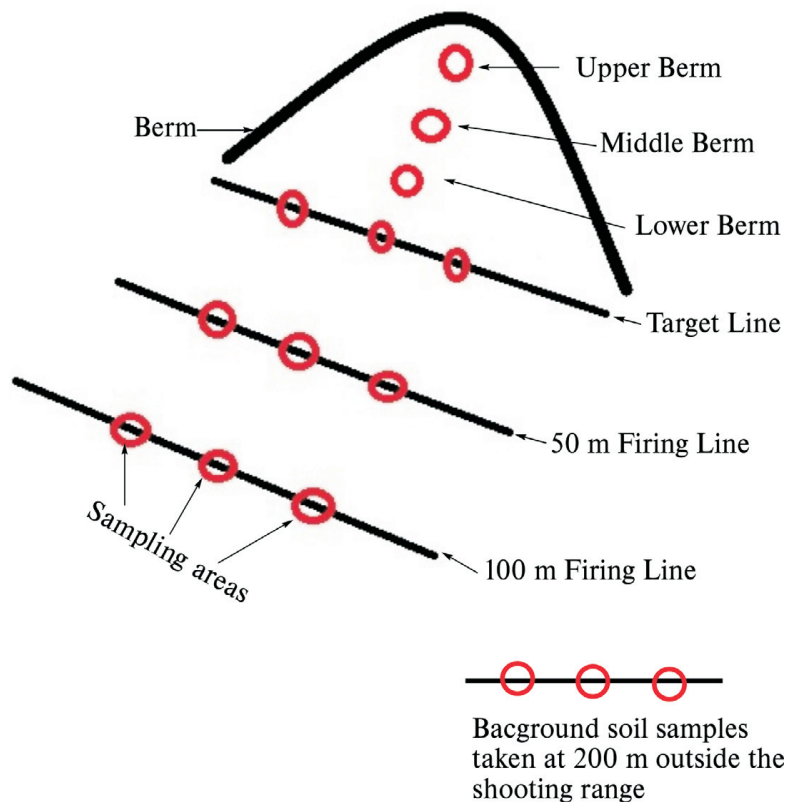

Figure 3 Schematic diagram of sampling areas in the shooting range. soils were collected from the areas that were not impacted by lead bullets outside the shooting range at a distance of $200 \mathrm{~m}$ from the shooting range. Butyrated zip-lock plastic bags were used to store the soil samples. The field soil samples were then transported to the laboratory to start the sequence of analyses.

\subsection{Soil Sample Preparation}

The quadruplicate soil samples collected from the three sampling areas at the berm (bottom, middle and upper), target line, 50 and $100 \mathrm{~m}$ position line were mixed together to make three composite soil samples representative of each position line. The soil samples were air dried and passed through a $2 \mathrm{~mm}$ stainless steel sieve to remove large particles such as rock pebbles, spent lead bullets and tree matter. A portion of the soil samples was pulverized using a manually operated Retsch RS 200 Vibratory Disk Mill at $700 \mathrm{rpm}$ for $3 \mathrm{~min}$ and then stored for X-Ray Diffraction (XRD) analysis. A series of $0.100 \mathrm{~g}$ of soil samples were digested in $25 \mathrm{~mL}$ of $10 \% \mathrm{HNO}_{3}$ for $16 \mathrm{~h}$ using the dry heating-block digestion procedure (USEPA Method 3050).

\subsection{Physical and Chemical Properties of Shooting Range Soils}

The physical and chemical properties of the shooting range soils such as $\mathrm{pH}$, organic matter $(\mathrm{OM})$, cation exchange capacity (CEC) and metal content were all determined using standard methods. The $\mathrm{pH}$ measurements were carried out by adding to $20 \mathrm{~g}$ of the homogenized soil sample $40 \mathrm{~mL}$ of deionized water and $0.01 \mathrm{M} \mathrm{CaCl}_{2}$ solution. The solutions were stirred vigorously. The slurry was allowed to settle for $30 \mathrm{~min}$. A calibrated crimson basic $20 \mathrm{pH}$ meter was used for $\mathrm{pH}$ measurements at $25^{\circ} \mathrm{C}$. The Walkley-Black procedure was used to measure the organic matter (OM) content of the soil samples. ${ }^{26}$ Cation exchange capacity (CEC) of the soils was determined using method 9081.

\subsection{Simulation of Acid Rain - Leaching Test}

There is a possibility of $\mathrm{Pb}$ to contaminate underground water under favourable environmental conditions. The synthetic precipitation leaching procedure (SPLP) has been widely used in areas highly polluted with $\mathrm{Pb}$ to assess the possibility of underground water contamination. ${ }^{27,28}$ This involves the use of a slightly acidified deionized water extraction fluid to simulate the acid rain. The acidification of deionized water was done using a mixture of $60 / 40 \mathrm{H}_{2} \mathrm{SO}_{4} / \mathrm{HNO}_{3}$ to achieve the appropriate $\mathrm{pH}$ of $4.2 \pm 0.05$. The SPLP Pb in the shooting range soils was extracted using this extraction fluid in the ratio of solid to liquid of 1:20 and determined using the USEPA method $1312 .^{29}$

\subsection{Fractionation Studies}

A sequential extraction process adapted from Tessier et al. (1979) was used to separate the berm soil $\mathrm{Pb}$ into different fractions so as to determine the mobility and availability of $\mathrm{Pb}^{30}$ The fractions of the soil are in the forms: water-soluble and exchangeable (WE); carbonate bound (CB); Fe-Mn oxides (FM); organic matter bound (OM) and the residual (RS) fractions. To better understand the potential health hazards from contamination with $\mathrm{Pb}$, the different chemical species in which $\mathrm{Pb}$ exist in the shooting range soils (free metal, metal-organic complexes and salts) were determined. The different $\mathrm{Pb}$ species and their reactivity with the specific target constituents of the soils help ascertain their mobility and bioavailability in the environment.

\subsection{X-Ray Diffraction (XRD) Analysis of Shooting Range Soils}

The chemical transformation of the weathered $\mathrm{Pb}$ bullets 
was determined by X-ray diffraction (X'pert Philips Electronic Instruments, Inc). The berm soils of the eight shooting ranges; MOG, TSH, MAK, TAB, SHO R1, SHO R2, PAJ R1 and PAJ R2 were used for this analysis. The $X^{\prime}$ pert data high score software was used to identify $\mathrm{Pb}$ minerals present in the soils. The pellet was prepared using pulverized soil samples. The current used was $30 \mathrm{~mA}$ and tension $45 \mathrm{kV}$ using $\mathrm{CuK} \alpha$ radiation and taking measurements from 5 to $70^{\circ} 2 \Theta .^{9}$

\subsection{Analysis for Total $\mathrm{Pb}$ in Shooting Range Soils}

Samples were digested using USEPA Method 3050 and analysed for total $\mathrm{Pb}$ concentrations using inductively coupled plasma optical emission spectrometry (ICP-OES; Perkin Elmer, Optima7300DV). Quality control samples included certified reference material (CRM) of soil, NCS DC 73320, obtained from the Botswana Geoscience Institute (Chemistry Lab).

\section{Results and Discussion}

\subsection{Distribution of Total $\mathrm{Pb}$ Contamination in Shooting Range Soils}

All the shooting ranges studied were contaminated with $\mathrm{Pb}$ (Fig. 4a-d). The highest total $\mathrm{Pb}$ concentrations were found in the berm soils. It is worth noting that the soils analysed for total $\mathrm{Pb}$ concentration are the soil particles of less than $2 \mathrm{~mm}$ in diameter obtained by sieving the soil samples through the $2 \mathrm{~mm}$ stainless steel sieve. TAB shooting range berm soils accumulated the highest total $\mathrm{Pb}$ concentration of $38386 \pm 10197 \mathrm{mg} \mathrm{kg}^{-1}$ followed by MAK at $25193 \pm 3338 \mathrm{mg} \mathrm{kg}^{-1}$ (Fig. 4a). The highest total $\mathrm{Pb}$ concentration experienced by TAB (established in 1995) shooting range can be attributed more to the frequency of use of the shooting range. The TAB shooting range belongs to the special force unit (Commando unit) of the Botswana Defence Force. The
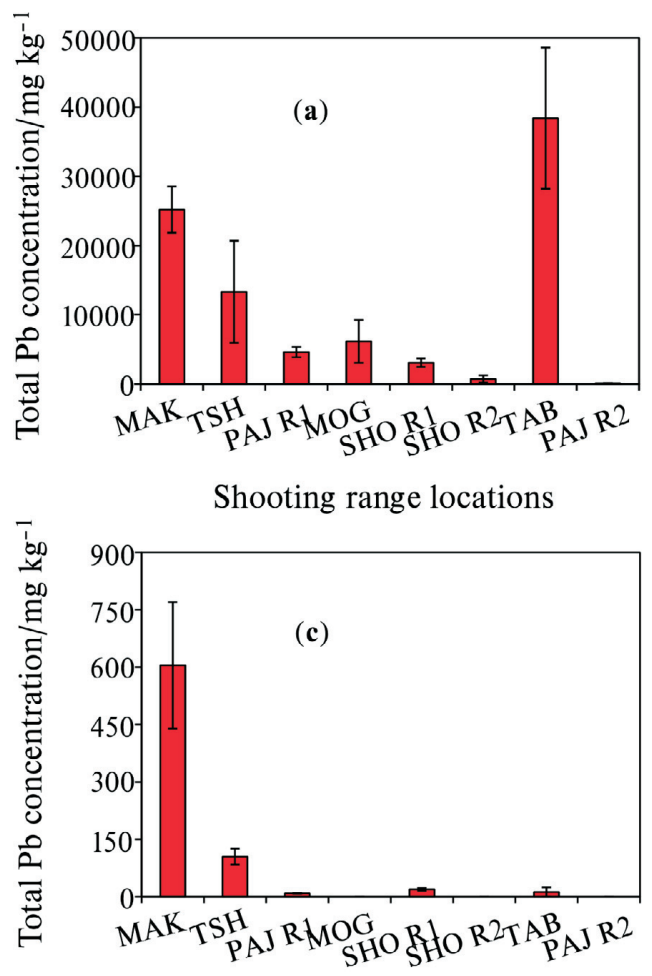

Shooting range locations special force unit carries out intensive shooting practices to sharpen their marksmanship skills. These shooting practices can occur as often as once a week to more than once a week. The MAK shooting range, even though older than the TAB range (established in 1983), has accumulated less concentration of $\mathrm{Pb}$ on its berm soils. This does show that the overall concentrations of $\mathrm{Pb}$ are more closely related to the frequency of shooting at each shooting range. These findings are consistent with the results obtained by Rooney and McLaren $(2000)^{31}$. The lowest total $\mathrm{Pb}$ concentrations were measured at the berm soil of PAJ R2 shooting range $\left(85 \pm 42 \mathrm{mg} \mathrm{kg}^{-1}\right)$ and SHO R2 $\left(728 \pm 527 \mathrm{mg} \mathrm{kg}^{-1}\right)$ as displayed in Fig. 4a. The PAJ R2 is a pistol range while the SHO R2 is an obsolete rifle range that has not been used for many years. According to military personnel, pistol firing is only restricted to use by military officers who are normally few in number, this may be a contributing factor to the small concentration of total $\mathrm{Pb}$ at the $\mathrm{PAJ} \mathrm{R} 2$ shooting range. Pistol ammunition contains less amount of $\mathrm{Pb}$ slug of about $52 \%$ as compared to assault rifles with over $80 \% \mathrm{~Pb}$ slug content. The less $\mathrm{Pb}$ content in pistol projectiles could be a contributing factor to the low pollution in pistol shooting range soils. The SHO R2 has not been in use for some few years. There is a high possibility that the weathered $\mathrm{Pb}$ has leached further underground with some of the $\mathrm{Pb}$ having been washed off the surface of the ground by runoff water from rain. In all eight shooting ranges studied, the highest total $\mathrm{Pb}$ accumulation occurred in the berm soils (Fig. 4). The highest total $\mathrm{Pb}$ concentration in the berm soils can be attributed to accumulation of lead bullets, projectiles and shots into the berm. Cao et al. (2003) ${ }^{9}$ found that the total $\mathrm{Pb}$ concentration in the berm soils was directly related to the build-up of bullets, shots and projectiles in the berm corroborating our results. The total $\mathrm{Pb}$ concentrations decreased as one moved away from berm to the target line, 50 and $100 \mathrm{~m}$ shooting lines. The target
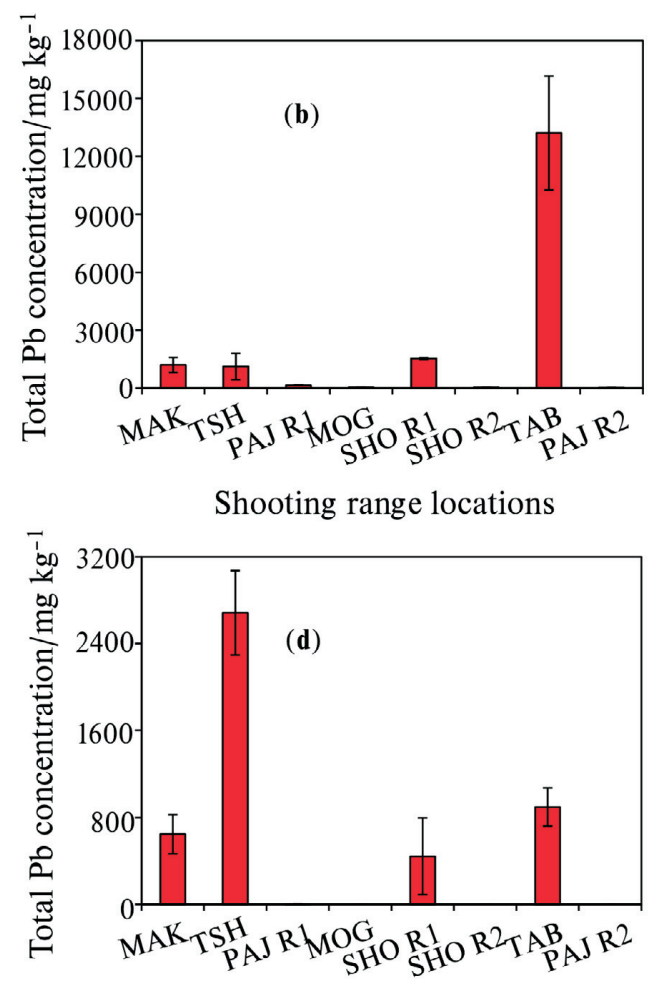

Shooting range locations

Figure 4 Total Pb concentrations of composite; (a) berm soils; (b) target line soils ; (c) $50 \mathrm{~m}$ from target line soils and (d) $100 \mathrm{~m}$ from target line soils at eight different shooting ranges found in southern and central Botswana, Mean of $n=3$; Standard error of the mean, $\delta_{\mathrm{x}}=\delta / \sqrt{ } n$, where $\delta=$ standard deviation. 
line soils total $\mathrm{Pb}$ concentrations are second highest to the berm soils total $\mathrm{Pb}$ concentrations (Fig. $4 \mathrm{~b}$ ). Target line total $\mathrm{Pb}$ concentrations were measured at $1200 \pm 320,149 \pm 17,45 \pm 3,1554 \pm 35$, $13204 \pm 2408$ and $13 \pm 6 \mathrm{mg} \mathrm{kg}^{-1}$ for MAK, PAJ R1, MOG, SHO R1, SHO R2, TAB and PAJ R2, respectively. The target line is closest to the berm, there is high possibility that some of the weathered $\mathrm{Pb}$ might have mobilised and migrated down the berm slope contributing to the high concentration of total $\mathrm{Pb}$ at the target line. Another contributing factor to the high concentrations of total $\mathrm{Pb}$ in the target line soils could be the $\mathrm{Pb}$ powder emitted due to the friction between the bullet and the target as the bullet pierced through the target. It is important to note that the total $\mathrm{Pb}$ concentrations at the $100 \mathrm{~m}$ shooting line were higher compared to the $50 \mathrm{~m}$ shooting line for most of the shooting ranges such as the TSH $\left(2681 \mathrm{mg} \mathrm{kg}^{-1}\right)$, TAB $\left(896 \mathrm{mg} \mathrm{kg}^{-1}\right)$, MAK $\left(647 \mathrm{mg} \mathrm{kg}^{-1}\right)$ and SHO R1 (442 $\left.\mathrm{mg} \mathrm{kg}^{-1}\right)$ at the $100 \mathrm{~m}$ shooting line compared to TSH (105 $\left.\mathrm{mg} \mathrm{kg}^{-1}\right), \mathrm{TAB}\left(71 \mathrm{mg} \mathrm{kg}^{-1}\right)$, MAK $\left(605 \mathrm{mg} \mathrm{kg}^{-1}\right)$ and SHO R1 (19 $\left.\mathrm{mg} \mathrm{kg}^{-1}\right)$ at the $50 \mathrm{~m}$ shooting line. According to military personnel, most of the shooting practice takes place at the $100 \mathrm{~m}$ shooting line implying that as bullets, shots and projectiles move through the barrel of the rifle there is friction created between the bullets and the barrel riffling's leading to the discharge of $\mathrm{Pb}$ powder into the $100 \mathrm{~m}$ shooting line soils leading to higher concentrations of total $\mathrm{Pb}$ at $100 \mathrm{~m}$ than at $50 \mathrm{~m}$ shooting lines. The background total $\mathrm{Pb}$ concentrations were less than $10 \mathrm{mg} \mathrm{kg}^{-1}$ in all the shooting ranges studied (Fig. 5). This implies that $\mathrm{Pb}$ mobility may be restricted within the shooting ranges and their immediate surroundings. Quality assurance was carried out through analysis of certified reference material, NCS DC73320 of known concentration of 20 ppm $\left(20 \mathrm{mg} \mathrm{kg}^{-1}\right)$. The CRM was subjected to the same experimental condition as the soil samples with average measurement of $17.3 \pm 0.6 \mathrm{mg} \mathrm{kg}^{-1}$ (mean \pm standard error of the mean). The accuracy of measurements was $<3 \%$ RSD, an indication of accuracy of the analytical methodology.

The mobility of $\mathrm{Pb}$ in the soil due to acid rain was simulated using the SPLP procedure. ${ }^{27}$ The SPLP Pb concentration was highest in the berm soils of TSH range at $787 \pm 8 \mathrm{mg} \mathrm{kg}^{-1}$ followed by PAJ R2 and TAB ranges at $448 \pm 4$ and $398 \mathrm{mg} \mathrm{kg}^{-1}$, respectively (Fig. 6). The lowest SPLP Pb concentration was recorded in the PAJ R2 soils with a concentration of $0.1 \pm 0.08 \mathrm{mg}$ $\mathrm{kg}^{-1}$. In all of the eight shooting ranges studied the SPLP Pb concentrations exceeded the USEPA $0.015 \mathrm{mg} \mathrm{kg}^{-1}$ critical level of hazardous waste. ${ }^{29}$ This indicates that some of the $\mathrm{Pb}$ may have leached out from the shooting range soils giving rise to possibility of surface and groundwater contamination.

\section{2. $\mathrm{Pb}$ Partitioning and Availability in Shooting Range Berm Soils}

Sequential extraction procedure is commonly used to ascertain the chemical mobility, availability, leaching and distribution of metals in the soil..$^{32}$ The partitioning of $\mathrm{Pb}$ in the different soil fractions is largely dependent on the chemistry and geochemistry of the soil such as its $\mathrm{pH}$, cation exchange capacity, organic matter content and presence of other chemicals in the soil. The sequential extraction method takes place with the assumption that the partitioning of the metal within each fraction is lowered with each successive extraction step. ${ }^{30}$ All the $\mathrm{Pb}$ in the shooting range berm soils were found to be linked to the carbonate fraction (CB), 46-68\% (Fig. 7). The berm soil Pb associated with the organic matter $(\mathrm{OB})$ was also found to be in substantial amounts of $2-47 \%$ followed by the Fe-Mn oxides (FM) bound $\mathrm{Pb}(1-37 \%$ ), water-soluble and exchangeable (WE) (0-19\%) and lastly the residual $\mathrm{Pb}(0-5 \%)$. The existence of $\mathrm{Pb}$ in the berm soils bound

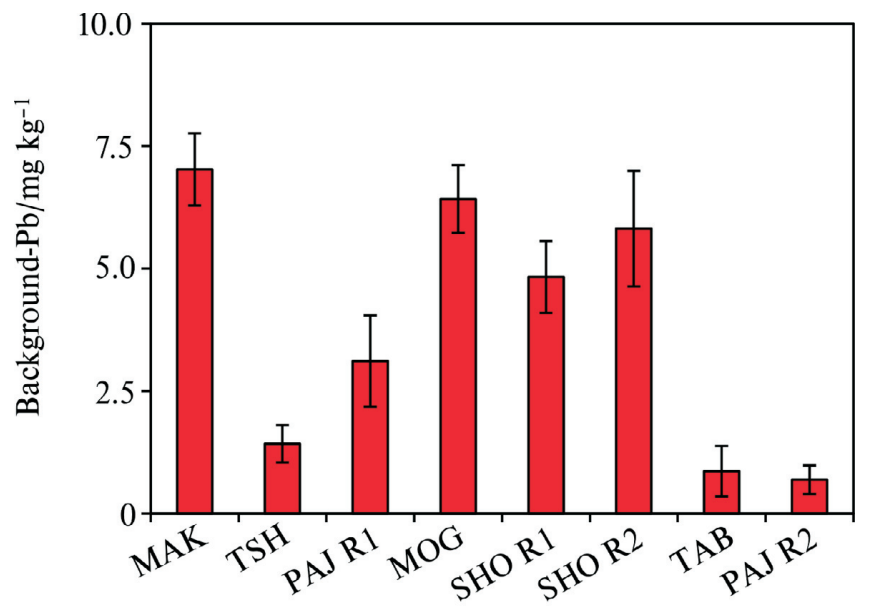

Shooting range locations

Figure 5 Background- $\mathrm{Pb}$ concentrations at eight different shooting ranges found in the southern and central Botswana. Mean of $n=3$; Standard error of the mean, $\delta_{x}=\delta / \sqrt{ } n$, where $\delta=$ standard deviation.

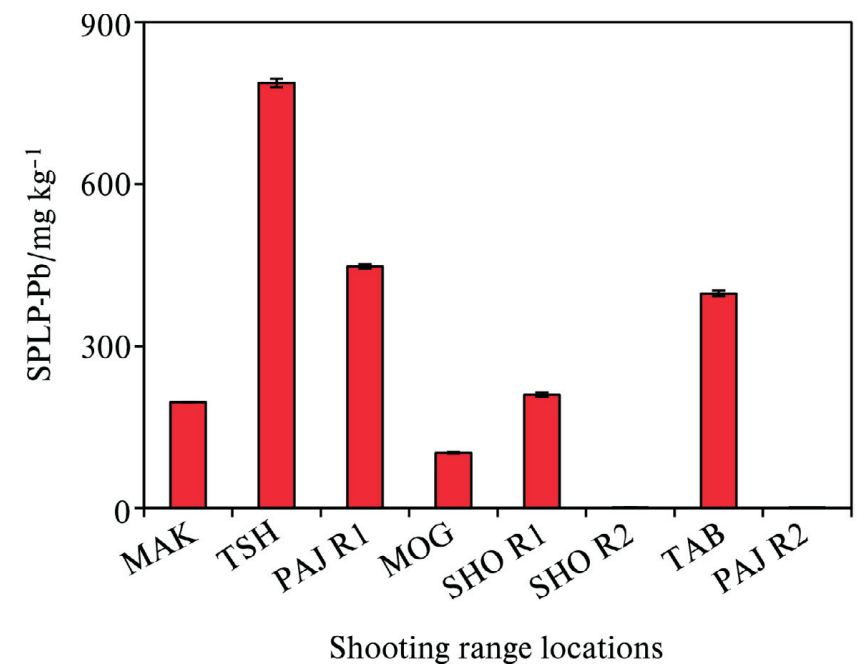

Figure 6 SPLP-Pb concentrations at eight different shooting ranges found in the southern and central Botswana. Mean of $n=3$; Standard error of the mean, $\delta_{\mathrm{x}}=\delta / \sqrt{ } n$, where $\delta=$ standard deviation.

mainly to the carbonate fraction (CB) can be attributed to the weathering processes of $\mathrm{Pb}$ bullets and shots such as oxidation of metallic $\mathrm{Pb}$ and carbonation of the oxidised $\mathrm{Pb}(\mathrm{PbO}) .{ }^{9}$ There was a correlation between the soil $\mathrm{pH}$ and the total $\mathrm{Pb}$ concentrations found in the shooting range soils studied. As shown in Table 2 below, $\mathrm{TAB}$ shooting range with the alkaline $\mathrm{pH}$ of 8.25 experienced the highest accumulation of total $\mathrm{Pb}$ in its soil. The alkaline $\mathrm{pH}$ is regarded as a favourable condition for the stability of $\mathrm{Pb}$ oxides and carbonates. This corroborates the fractionation results (Fig. 7) where considerable amounts of $\mathrm{Pb}$ were associated with the carbonate fraction. Soil moisture has been reported to play a crucial role in the weathering of $\mathrm{Pb}$ bullets and shots. The soil moisture helps in the erosion and corrosion of $\mathrm{Pb}$ bullets and shots through the formation of a water layer on the $\mathrm{Pb}$ bullets and shots surfaces making it easy for the diffusion of atmospheric gases to reach and attack the metal surfaces leading to the formation of $\mathrm{Pb}$ weathering products such as $\mathrm{Pb}$ oxides, sulphates and carbonates and subsequent dissolution of these $\mathrm{Pb}$ compounds into the shooting range soils. ${ }^{33}$ The areas studied have a good annual rainfall supply as shown in Fig. 2. Rainfall amounts have been recorded to as high as $103 \mathrm{~mm}$ (December 2013) for TAB (with total $\mathrm{Pb}$ concentration of $38386 \pm 10197 \mathrm{mg} \mathrm{kg}^{-1}$ ) shooting 


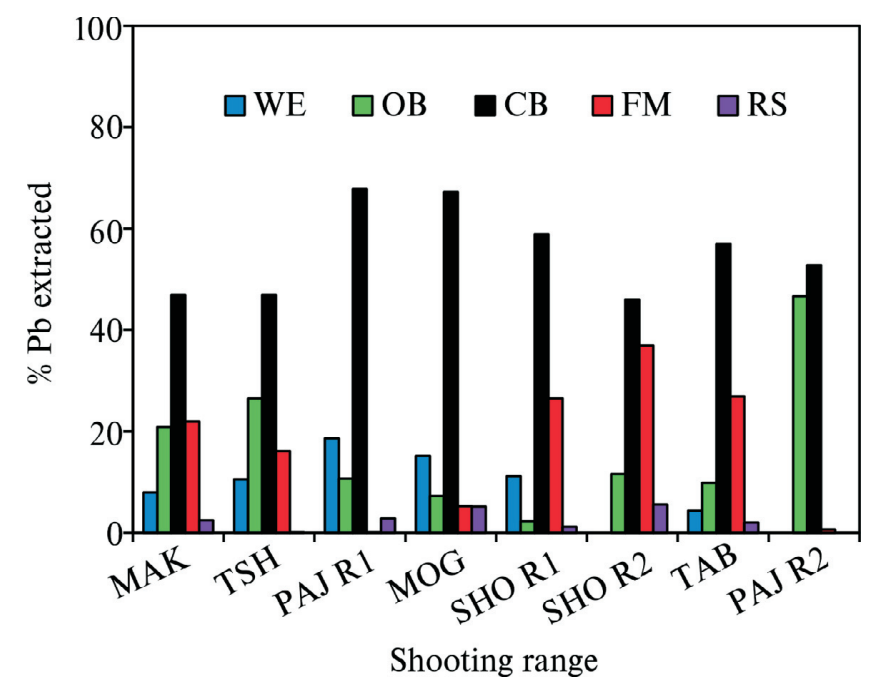

Figure 7 Chemical fractionation of $\mathrm{Pb}$ in shooting range soils for different shooting ranges found in the southern and central Botswana. WE = water-soluble and exchangeable, $\mathrm{OB}=$ organic-bound, $\mathrm{CB}=$ carbonate-bound, $\mathrm{FM}=\mathrm{Fe}-\mathrm{Mn}$ oxides bound and $\mathrm{RS}=$ residual fraction.

Table 2 Shooting range soils chemical properties from eight shooting ranges in southern and central Botswana.

\begin{tabular}{lccc}
\hline Range & $\mathrm{pH}_{\mathrm{w}}$ & Organic matter $\pm \delta \mathrm{a} / \%$ & $\mathrm{CEC}^{\mathrm{b}} \pm \delta / \mathrm{cmol} \mathrm{kg}^{-1}$ \\
\hline TAB & 8.25 & $0.35 \pm 0.08^{\mathrm{c}}$ & $10.75 \pm 0.16$ \\
MAK & 6.64 & $1.62 \pm 0.02$ & $8.00 \pm 0.20$ \\
TSH & 6.80 & $0.69 \pm 0.08$ & $5.34 \pm 0.58$ \\
MOG & 7.07 & $0.62 \pm 0.11$ & $5.01 \pm 0.05$ \\
PAJ R1 & 6.95 & $0.81 \pm 0.15$ & $5.95 \pm 0.13$ \\
SHO R1 & 7.15 & $0.66 \pm 0.12$ & $7.07 \pm 0.15$ \\
SHO R2 & 7.20 & $0.58 \pm 0.02$ & $3.50 \pm 0.02$ \\
PAJ R2 & 8.70 & $0.77 \pm 0.08$ & $11.95 \pm 0.38$ \\
\hline
\end{tabular}

${ }^{\mathrm{a}} \delta=$ Standard deviation.

${ }^{\mathrm{b}}$ Cation exchange capacity.

${ }^{\mathrm{c}}$ Mean \pm standard deviation $(n=3)$.

range for the year June 2013 to July 2014. Other months in the same year for $\mathrm{TAB}$ shooting range have recorded rainfall amounts of as high as $50 \mathrm{~mm}$ (November 2013 and March 2014). Other shooting ranges such as SHO R1, SHO R2, PAJ R1 and PAJ $\mathrm{R} 2$ have experienced rains as high as $230-320 \mathrm{~mm}$ (Fig. 2). Even though the frequency of shooting in these ranges was not high, significant amounts of total $\mathrm{Pb}$ concentrations were found at SHO R1 and PAJ R1 measured at $3075 \pm 611$ and $4608 \pm 748 \mathrm{mg}$ $\mathrm{kg}^{-1}$, respectively (Fig. 4). Organic matter has been found to be an important factor in the weathering of $\mathrm{Pb}$ bullets and shots. The presence of organic matter in the soil accelerates the transformation of metallic $\mathrm{Pb}$ into its $\mathrm{Pb}$ oxides and carbonates. This takes place through the production of $\mathrm{CO}_{2}$ by microbial organisms in the soil rich in organic matter making the $\mathrm{CO}_{2}$ available for the weathering of lead bullets and shots into $\mathrm{Pb}$ oxides and carbonates. ${ }^{34}$ Organic matter was high in all of the shooting ranges studied, $0.35-1.62 \%$ (Table 2), a favourable condition to the weathering of $\mathrm{Pb}$ in soil leading to increased mobility and availability of $\mathrm{Pb}$ in the shooting range soils. The soil cation exchange capacity (CEC) plays a crucial role in the mobility and bioavailability of $\mathrm{Pb}$. The higher the CEC of the soil the higher the binding capacity of $\mathrm{Pb}$ leading to significant reduction in $\mathrm{Pb}$ mobility and bioavailability and vice versa. ${ }^{9} \mathrm{TAB}$ and PAJ R2 experienced the highest CEC values of 10.75 and $11.95 \mathrm{cmol} \mathrm{kg}^{-1}$, respectively and SHO R2 recorded the least CEC of $3.50 \mathrm{cmol} \mathrm{kg}^{-1}$. Coupled with other factors such as higher $\mathrm{pH}$ of 8.25 and frequency of use, the highest total $\mathrm{Pb}$ concentrations in berm soils were recorded in $\mathrm{TAB}$ shooting range (Fig. 4). Total $\mathrm{Pb}$ concentrations of PAJ R2 were the lowest even though this range has high soil $\mathrm{CEC}$ and high soil $\mathrm{pH}$. The main reason for this lower $\mathrm{Pb}$ concentration is that, PAJ R2 is a pistol range used to fire $5.56 \mathrm{~mm}$ ammunition that contains the least amount of $\mathrm{Pb}$, about $56 \%$ compared to other ranges whereby all bullets of $7.62 \mathrm{~mm}$, $5.56 \mathrm{~mm}$ and $0.50 \mathrm{~mm}$ with $\mathrm{Pb}$ content of $77 \%, 56 \%$ and $1 \%$ are shot into the berm soils. ${ }^{35}$ In addition this range is situated in a military training camp and it is used less frequently for training military officers in shooting pistol firearms, about four to seven times in a month for six months in a year. SHO R2 soils have the lowest CEC with $\mathrm{pH}$ values in the neutral region (7.15). This range is obsolete and the low soil CEC may have provided a favourable condition for the solubility and mobility of $\mathrm{Pb}$.

\subsection{Mineralogical and Chemical Transformation of \\ Weathered $\mathrm{Pb}$ in Shooting Range Soils}

The weathering products of $\mathrm{Pb}$ bullets and shots at all the eight shooting ranges studied were predominantly carbonates specifically cerussite $\left(\mathrm{PbCO}_{3}\right)$ and hydrocerussite $\left(\mathrm{PbCO}_{3} \mathrm{H}_{2} \mathrm{O}\right)$ as shown on the XRD plots in Fig. 8. Cao et al.'s (2003) study on $\mathrm{Pb}$ transformation in shooting range soils has shown that the abrasion process of $\mathrm{Pb}$ bullets and shots takes place via a two steps mechanism involving the oxidation of metallic $\mathrm{Pb}$ and hydration and carbonation in the presence of $\mathrm{H}_{2} \mathrm{O}$ and $\mathrm{CO}_{2}$. The XRD results agree well with the fractionation studies (Fig. 7) which showed that the carbonate bound $\mathrm{Pb}$ was the most predominant in all the eight shooting ranges investigated. The soil $\mathrm{pH}$ plays an important role in the corrosion of $\mathrm{Pb}$ shots and bullets and formation of weathering products. At MOG shooting range, hydrocerussite was the only dominant $\mathrm{Pb}$ carbonate weathering product with no trace of other $\mathrm{Pb}$ carbonates. This could be due to the favourable high $\mathrm{pH}$ which is slightly above neural into the alkaline region. The other seven shooting ranges had a mixture of both cerussite and hydrocerussite. A study by Dermatas et al. (2007) was able to show that the carbonates are some of the dominant weathering products of $\mathrm{Pb}$ bullets and shots in shooting range soils. ${ }^{36}$

\section{Conclusions}

The total $\mathrm{Pb}$ concentrations in the berm soils in the seven of the eight shooting ranges studied exceeded the USEPA critical value of $400 \mathrm{mg} \mathrm{kg}^{-1}$. The PAJ R2 shooting range showed total $\mathrm{Pb}$ concentration of less than $400 \mathrm{mg} \mathrm{kg}^{-1}$ due to the fact that it is a pistol shooting range. Pistol ammunition contains less amount of $\mathrm{Pb}$ slug of about $52 \%$ as compared assault rifles with over $80 \%$ $\mathrm{Pb}$ slug content. The SPLP Pb concentrations in all of the eight shooting ranges studied exceeded the USEPA $0.015 \mathrm{mg} \mathrm{kg}^{-1}$ critical level. This implies that there is potential for the polluted soils to contaminate both surface and groundwater. Soil physical and chemical properties have strong impact on the weathering of $\mathrm{Pb}$ shots and bullets. The high $\mathrm{pH}$ and organic matter experienced by the soils in the shooting ranges investigated may have contributed significantly to the transformation of $\mathrm{Pb}$ in to the different weathering products. The XRD patterns show that cerussite and hydrocerussite were the predominant weathering products in all of the eight shooting ranges in this study. Our findings suggest that best shooting range management practices are required as a matter of urgency to arrest this pollution problem before it spirals out of control. The application of phosphate rock has been found to significantly immobilize $\mathrm{Pb}$ and reduce its solubility in the soil. 
S. Afr. J. Chem., 2017, 70, 21-28,

$<$ http://journals.sabinet.co.za/sajchem/>.
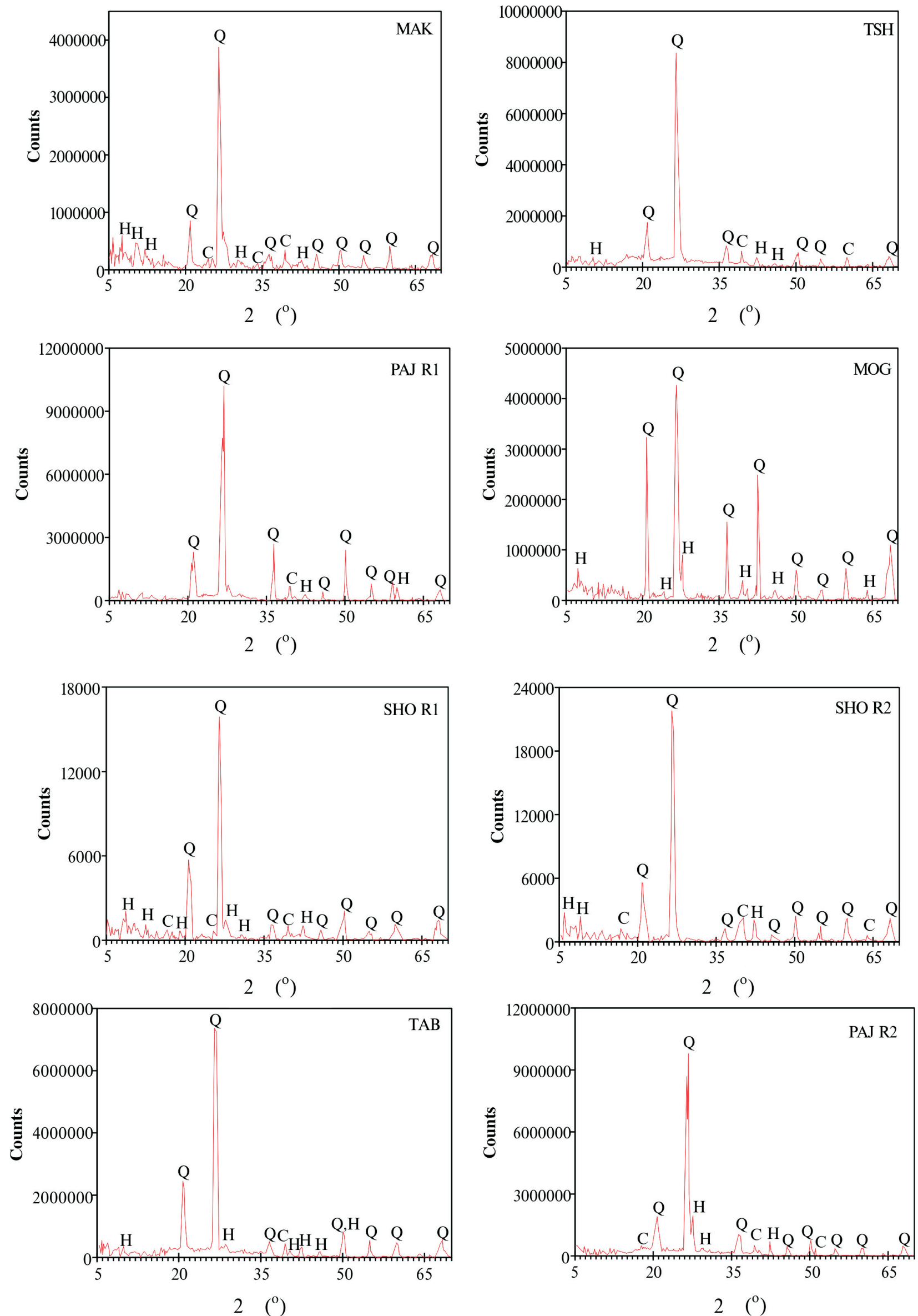

Figure $8 \mathrm{X}$-ray diffraction analysis pattern indicating the weathering products of $\mathrm{Pb}$ bullets in the eight shooting range soils found in southern and central Botswana. $\mathrm{Q}=$ quartz, $\mathrm{C}=$ cerussite and $\mathrm{H}=$ hydrocerussite. 


\section{Acknowledgements}

This research is sponsored wholly by the Botswana International University of Science and Technology (BIUST). The authors would like to thank Botswana Defence Force (BDF) for availing their shooting ranges to be used in this study. An appreciation is also extended to the Botswana Geoscience Institute (BGI) for their assistance with their ICP-OES and XRD instruments for the chemical analysis.

\section{References}

1 D. Dermatas, M. Dadachov, P. Dutko, N. Menounou, P. Arienti and G. Shen, Weathering of lead in Fort Irwin firing range soils, Global Nest: The Int. J., 2004, 6, 167-175.

2 US Environmental Protection Agency (USEPA), EPA-902-B01-001: Best management practices for lead at outdoor shooting ranges: United States Environmental Protection Agency Region 2. EPA-902B01-001. 2001.

3 W. Luo, R.A. Verweij and C.A.M. Van Gestel, Toxicity of Pb contaminated soils to the oribatid mite Platynothrus peltifer, Ecotoxicol., 2015, 24, 985-990.

4 C.A. Hui, Lead distribution throughout soil, flora and an invertebrate at a wetland skeet range, J. Toxicol. Environ. Health A., 2002, 65, 1093-1107.

5 J. VanBon and J.J. Boersema, Sources, effects and management of metallic lead pollution: the contribution of hunting, shooting and angling, Contam. Soil., 1988, 3, 269-271.

6 T. Astrup, J.K. Boddum and T.H. Christensen, Lead distribution and mobility in a soil embankment used as a bullet stop at a shooting range, J. Soil Contam., 1999, 8, 653-665.

7 R. Bruell, N.P. Nikolaidis and R.P. Long, Evaluation of remedial alternatives of lead from shooting range soil, Environ. Eng. Sci., 1999, 16, 403-414.

8 V.J. Camobreco, B.K. Richards, T.S. Steenhuis, J.H. Peverly and M.B. McBride, Movement of heavy metals through undisturbed and homogenized soil columns, Soil Sci., 1996, 161, 740-750.

9 X. Cao, L.Q. Ma, D. Hardison Jr and W.G.Harris, Weathering of lead bullets and their environmental effects at outdoor shooting ranges, J. Environ. Qual., 2003, 32, 526-534.

10 L.Q. Ma, D. Hardison Jr, W.G. Harris, X. Cao and Q. Zhou, Effects of soil property and soil amendment on weathering of abraded metallic $\mathrm{Pb}$ in shooting ranges, Water Air Soil Poll., 2007, 178, 297-307.

11 K.Y. Lee and K.W. Kim, Heavy metal removal from shooting range soil by hybrid electrokinetics with bacteria and enhancing agents, Environ. Sci. Technol., 2010, 44, 9482-9487.

12 Y. Luo and A. Hong, Oxidation and dissolution of lead in chlorinated drinking water, Adv. Environ. Res., 1997, 1, 84-97.

13 W.L. Lindsay, Chemical equilibria in soils, John Wiley, New York, USA, 1979.

14 Z. Lin, B. Comet, U. Qvarfort and R. Herbert, The chemical and mineralogical behaviour of $\mathrm{Pb}$ in shooting range soils from central Sweden, Environ. Pollut., 1995, 89, 303-309.

15 K. Murray, A. Bazzi, C. Carter, A. Ehlert, A. Harris, M. Kopec, J. Richardson and H. Sokol, Distribution and mobility of lead in soils at an outdoor shooting range, J. Soil Contam., 1997, 6, 79-93

16 M. Chen, S.H. Daroub, L.Q. Ma, W. G. Harris and X. Cao, Characterization of lead in soils of a rifle/pistol shooting range in central Florida, USA, Soil Sediment Contam., 2002, 11, 1-17.

17 J.R. Craig, J.D. Rimstidt, C.A. Bonnaffon, T.K. Collins and P.F. Scanlon,
Surface water transport of lead at a shooting range, B. Environ. Contam. Tox., 1999, 63, 312-319.

18 W. Stansley, L. Widjeskog and D.E. Roscoe, Lead contamination and mobility in surface water at trap and skeet ranges, B. Environ. Contam. Tox., 1992, 49, 640-647.

19 C.P. Rooney, R.G. Mclaren and R.J. Cresswell, Distribution and phytoavailability of lead in a soil contaminated with lead shot, Water Air Soil Poll., 1999, 116, 534-548.

20 A. Mellor and C. McCartney, The effects of lead shot deposition on soils and crops at a clay pigeon shooting site in northern England, Soil Use Manag., 1994, 10, 124-129.

21 D.E. Koeppe, The uptake, distribution and effect of cadmium and lead in plants, Stevens Report, Stevens Institute of Technology, 1977, 7, 197-206.

22 M. Zhai, O. Totolo, M.P. Modisi, R.B. Finkelman, S.M. Kelesitse and M. Menyatso, Heavy metal distribution in soils near Palapye, Botswana: an evaluation of the environmental impact of coal mining and combustion on soils in a semi-arid region, Environ. Geochem. Health., 2009, 31, 759-777.

23 B. Mbongwe, B.R. Barnes, J. Shabane, M. Zhai, S. Rajaram and S. Mpuchane, Exposure to lead among children aged 1-6 years in the city of Gaborone, Botswana, J. Environ. Health Res., 2010, 10, 17-26.

24 E. Kgosiesele and L. Zhaohui, An evaluation of waste management in Botswana: achievements and challenges, N. Y. Sci. J., 2010, 3, 37-42.

25 Soil map of the Republic of Botswana, soil mapping and advisory services project $\mathrm{FAO} / \mathrm{BOT} / 85 / 011,1990$.

26 F. Gelman, R. Binstock and L. Haliez, Application of the WalkelyBlack titration for the organic carbon quantification in organic rich sedimentary rocks, Fuel, 2012, 96, 608-610.

27 R. Peddicord, Synopsis of applications and limitations of TCLP and SPLP at outdoor shooting ranges. Newtown, CT: Facility development series No. 4, National Shooting Sports Foundation, pp. 1-12. 1998.

28 S. Reid and S.Z. Cohen, A new tool to predict lead mobility in shooting range soils: Predicting SPLP results. Amherst, University of Massachusetts: The 16th Annual International Conference on Contaminated Soils, Sediments and Water, 2000.

29 US Environmental Protection Agency (USEPA), Test Methods for Evaluation of Solid Waste, vol. IA, Laboratory Manual Physical/Chemical Methods, SW 846, 40 CFR Parts 403 and 503. 3rd edn. US Government Printing Office, Washington, DC, 1995.

30 A. Tessier, P.G.C. Campbell and M. Bisson, Sequential extraction procedure for the speciation of particulate trace metals, Anal. Chem., 1979, 52, 844-851.

31 C.P. Rooney and R.G. McLaren, Distribution of soil Pb contamination at clay target shooting ranges, Australas. J. Ecotoxicol., 2000, 6, 95-102.

32 A.O. Fayiga, U. Saha, X. Cao and L.Q. Ma, Chemical and physical characterization of lead in three shooting range soils in Florida, Chem. Speciat. Bioavailab., 2011, 23, 148-154.

33 E. Rocca and J. Steinmetz, Inhibition of lead corrosion with saturated linear aliphatic chain monocarboxylates of sodium, Corros. Sci., 2001, 43, 891-902.

34 Z. Lin, Secondary mineral phases of metallic lead in soils of shooting ranges from Orebro County, Sweden, Environ. Geol., 1996, 27, 370-375.

35 M. Bricka, Soil Treatments to Limit Lead Mobility. Fourth National Shooting Range Symposium. 2000.

36 D. Dermatas and M. Chrysochoou, 2007. Lead particle size and its association with firing conditions and range maintenance, implications for treatment, Environ. Geochem. Health, 2007, 29, 347-355. 